\title{
VECTOR AUTOREGRESSIVE MODELLING OF KENYAN ECONOMIC UNCERTAINTY OF THE COVID-19 PANDEMIC ON STOCK AND OIL MARKETS VOLATILITY
}

\author{
Maket Juma Isaiah \\ $\mathrm{PhD}$ student, Doctoral School of Economics, University of Szeged, Hungary \\ DOI: 10.46609/IJSSER.2020.v05i11.011 URL: https://doi.org/10.46609/IJSSER.2020.v05i11.011
}

\begin{abstract}
The widening uncertainty related to COVID-19 has stressed the business cycle of both local and global economy. The adverse effects of imbalances of demand and supply of oil products as well as stock returns pose a great threat to economic certainty. This paper focused on analysing the effect of economic uncertainty of the COVID-19 pandemic on oil and stock markets volatility in Kenya using Vector Autoregressive (VAR) model. The study considered a sampling period of between $13^{\text {th }}$ March, 2020 to $30^{\text {th }}$ September, 2020, yielding 202 observations. The study followed a purposive sampling technique in selecting the study sample size of daily data of COVID-19 new death and new infection cases, oil prices, number of days of travel bans and stock prices. The paper demonstrates that a positive shock of economic uncertainty caused by COVID-19 pandemic results to a decrease in the oil prices during the impact period. In regards to stock market volatility, the findings indicate that increase in new cases and new deaths creates worst economic uncertainty associated with travel bans and business restrictions thereby increasing the stock market volatility as several stock investors lose confidence in the market. Therefore, in light of this, concerted efforts should be put in place by the Kenyan government so as to speed the economic recovery. These may include easing on business travel restrictions and reduced interest rates. This will increase money supply and by extend result into increased lending to the business investments.
\end{abstract}

Key Words: Economic Uncertainty, COVID-19 Pandemic, Oil Prices, Stock Prices, Volatility

\section{INTRODUCTION}

\section{Background and Justification of the Study}

At the beginning of May, 2020, the global outbreak of COVID-19 had hit over 112 nations all over the world (Worldometer, 2020). The disease started as a mere pneumonia started by 


\section{International Journal of Social Science and Economic Research}

ISSN: $2455-8834$

Volume:05, Issue:11 "November 2020"

unjustified cause in Wuhan, China on $31^{\text {st }}$ December, 2019. As of $11^{\text {th }}$ March, 2020, the epidemic was pronounced a global pandemic (WHO, 2020). Kenya, one of the African states announced its first case two days later, $13^{\text {th }}$ March, 2020. As of now, Kenya stands out as a fairly hit African nation with 707 registered deaths and 38, 378 total confirmed cases as per the recordings of Worldometer on $1^{\text {st }}$ October, 2020.

As part of the measures of curbing the spread of the disease, Kenyan government reacted to the outbreak by imposing several measures. The measures comprised of complete shutdown of schools and institutions of higher learning, restaurants, food joints, recreation and leisure centers. Further, the situation prompted the government to impose travel bans to and out of major cities such as Nairobi, Mombasa, Kilifi and Lamu counties. All business operations such as hotel and hospitality industries, gym services and places of worship were closed down. The government allowed essential service providers to crisscross the regions. Further, the government provided various economic stimulus packages such as zero rating the taxes of income earners of between Kshs. 0-24, 000, lowering of Pay as You Earn tax from 30\% to 25\%, increased loan repayment period for business people and establishment of national emergency fund (National Treasury, 2020). Further, the estimations by the Kenya's National Treasury revealed massive plunge in the real GDP growth as well as massive job losses. Thus, in an overall view, the fluctuations of the Kenyan economic policies are uncertain as far as the COVID-19 situation is concerned.

In order to present the current scenario and what may result into in future, the paper provides a comprehensive analysis of economic uncertainty of Kenya due to COVID-19 pandemic. This follows theoretical analysis of other research work carried out regarding the subject. Although handful of studies have been carried, few or none at all has considered the petroleum products and the stock markets in the context of Kenyan economy despite its suitability for analysis. For instance, the drastic increase in economic uncertainty during the present corona virus pandemic has enormous effect on the general global scope of financial and economic investment. Superlatively, rising uncertainty regarding the COVID-19 pandemic is associated with greatly decreasing demand and disgruntled economic circumstance, as well as the financial activity (Baumeister \& Hamilton, 2019).

The link between oil and stock markets have been reinforced more by contribution of investors in energy markets, thus creating new avenues through which investors' thoughts can trip over other markets. Irrefutably, (Demirer, 2020) posited that financial threats hold the significant projection data in volatility of oil market prices, even after controlling the supply and demand forces and the related shocks in energy and commodity markets. This describes the presence of exclusive threat transmission canals amongst markets of stock and oil, driven by non-cash flow causes that cause the effect of changes in stockholders' sentiments via the threat payment pegged on the recommended performances. 
International Journal of Social Science and Economic Research

ISSN: 2455-8834

Volume:05, Issue:11 "November 2020"

Irrespective of the transmission channel between the oil and stock shocks, dependable estimates of oil price volatility are important for the placement of prices on the financial assets as well used for calculating optimal hedging positions, to cut down the levels of oil price associated threats of cash inflow streams. Inspired by the increasing engagement of asset investors in goods such as oil, and a rise in twofold variations across the two markets particularly during market uncertainty caused by the pandemic (Badshah, 2019), great volumes of recent researches have given attention on the spill over shocks from the oil to stock markets, and the forecasting force of stock market shocks in excess of volatility of the oil market prices (Demirer, 2020).

Consequently, an increasing literature strand has conducted the role of different measures of market uncertainties, in projecting the oil prices' volatility (Gkilla, 2020). However, notwithstanding of the erupting sternness of COVID-19 pandemic, the scholarly works don't provide sufficient evidence on the ability of uncertainty linked to various infectious epidemics in predicting the volatility of prices of energy markets in developing nations such as Kenya. Therefore, VAR modelling of the impact of economic uncertainty caused by COVID-19 pandemic on stock and oil markets volatility in Kenya adds to the existing literature.

The study sought to address the following research questions;

i. What is the effect of economic uncertainty of COVID-19 pandemic on oil market volatility?

ii. What is the effect of economic uncertainty of COVID-19 pandemic on stock market volatility?

\section{The Structure of the Paper}

The paper is organized into five sections; The first section of this paper entails the background and justification of the study concept with focus on economic uncertainty of COVID-19 pandemic on oil and stock market volatility with the aim of bringing out the real problem situation. Section two comprises of the theoretical review which entails description of study variables and empirical review which, that comprises of reviewing the previous studies. The third section of the paper entails methodological background where the paper explains the VAR model and analysis of the data. The fourth section comprises of data analysis and presentation of findings. Conclusion, policy recommendations and suggestion for further research will be presented in the fifth section.

\section{LITERATURE REVIEW}

Theoretical review 


\section{International Journal of Social Science and Economic Research}

ISSN: $2455-8834$

Volume:05, Issue:11 "November 2020"

This study focused on analysing the economic uncertainty of COVID-19 pandemic on oil and stock market volatility. Economic uncertainty signifies that the future economy's outlook is unpredictable. Simply put, it refers to a greater likelihood of adverse economic events occurring in the future (Baker, 2012).

Volatility of oil or stock market refers to the degree to which the prices of oil or stocks fluctuate over a specific time. Volatility is not directly observed, rather it is estimated based on the changes in the prices of oil or stocks (Sadorsky, 2006).

\section{Empirical Review}

The current COVID-19 health crisis presents both economic and health concerns. Several researchers such as Loayza and Pennings (2020) forecast that it may exceed the Global Financial Crisis of between 2008 and 2009. At this fragile time, policymakers all over the globe are concerned about the rising financial crisis as well as the economic upheavals it may pose to the entire global economy. As several posit, the effectiveness of any nation's ability to respond to shocks and provide support is ascertained by the governance quality (Chuah, 2020). Therefore, both long and short run uncertainty of policy of a nation generated by the COVID-19 state is a matter of excessive worry to business enterprises, economic entities and policy regulators and all in general. A set of both long and short run responses will be needed by the regulatory bodies and governments of every economy (McKibbin and Fernando, 2020).

A numerous number of the recent research has focused on the economic uncertainty and stock market impacts of COVID-19 epidemic (Barker, 2020). The greatest impact of COVID-19 impelled great economic uncertainty on developed nations like United States of America's real Gross Domestic Product (Barker, 2020). The author further indicates that the corona virus pandemic has paused unavoidable positive influence on stock market volatility if it is compared with the specific influence of other several infectious epidemics. Ma (2020) adds an indication of an unswerving worst influence on real GDP growth for 21 countries and of great adversative stock market outcome.

Zaremba (2020) conducted a research about effect of non-pharmaceuticals responses to corona epidemic on volatility of stock market. The study considered 67 economies and the findings suggested that government policy measures impact on the stock market volatility robustly and significantly. Similarly, Zhang (2020) noted that the unpredictability related to economic loses of COVID-19 has influenced on stock market by rendering it highly volatile. Moreover, Al-Awadhi (2020) pointed out that daily rises in death and new case of corona pandemic are negatively linked with stock market returns. 


\section{International Journal of Social Science and Economic Research}

ISSN: $2455-8834$

Volume:05, Issue:11 "November 2020"

Dietrich (2020) carried out a household survey concerning anticipations about the general impact of corona pandemic in USA. The study findings evidenced a high standard deviation in person's reactions, depicting the economic costs uncertainty due to COVID-19 epidemic. Dietrich (2020) further reiterates that monetary measure is undertaken in the short term; nevertheless, the impact on the potential outcome cannot be outstripped by the monetary policy within the medium run.

The association between oil and stock prices has been intensively explored in the research works provided the financialization of the markets of commodities such as oil (Balcilar\& Wen ,2019). Nevertheless, the relationship between stock and oil markets' volatilities have been given meagre attention. Liu and Illing (2019) found out that oil price's shocks signify the selection in stock market distress in Canadian energy sector. Ideally, financial burden cases effect the financial market returns and creation of the volatility as well, whereas the stock and oil price levels are strongly linked. The recent investigation in this area has indicated a bidirectional association amongst oil and stock volatility (Basher \& Sadorsky, 2016).

Another line of literature has carried out investigation about the association between the economic unpredictability and prices of oil commodity, resulting to the economic uncertainty index that was developed by Barker (2016). This interaction is specifically significant for nations like United States of America, the dollar being the mode of transaction in oil markets. Prices of oil affect the forecasted values of the macroeconomic variables. Antonakakis (2014) and Kang (2017) show that shocks of oil prices influence the economic uncertainty of United States of America. The authors report non-linear effect of economic uncertainty on prices of oil. Degiannakis (2018) with focusing on the oil price shocks, document a time changing influence on the economic improbability of US as well as the stock unpredictability in particular periods.

The link between volatility of oil price and economic uncertainty indicate the existence of opposite causality condition. Chen (2020) applied discrete wavelet transformation approach. The findings from the study pointed out that the volatility of oil price has a positive impact on economic impulsiveness. These findings were in line with the findings of Diebold and Yilmaz (2012) who suggested that economic unpredictability acts negatively on the volatility of oil prices and the converse holds.

Focusing on the utilization of copula technique, Aloui (2016) indicate that a rise in economic uncertainty index pause a positive impact on oil price volatility during periods that precede outburst in stock market crises. Shahzad (2017) applied non-parametric causality-in-quantile technique in carrying out investigation about causal effect of investor's utterances and economic uncertainty on oil market prices. In the same line, Albulescu (2019) implemented a distinct technique and indicate that the economic uncertainty in United States of America affects the linkage between stock and oil market prices as a result of global pandemic. 
International Journal of Social Science and Economic Research

ISSN: 2455-8834

Volume:05, Issue:11 "November 2020"

Yang and Yang., (2019) conducted a study about association between volatility of oil price and economic uncertainty and observed that there is absence of short run link between the two variables. Nevertheless, there is strong relationship in both long and medium run. Similarly, Yang (2019) found out that there is association in both short run and long run between economic uncertainty and volatility of oil prices. Hailemariam (2019) conducted a study regarding the association between volatility of oil price and economic uncertainty. The results indicated the existence a negative relationship between the two variables.

Baumeister and Peersman (2013) presents an empirical highlight by pointing out that a decline in the elasticity of prices of the supply and demand of oil is essential economic channel that describes negative interaction between price volatility and oil production. However, while there is existence of some strands of literature evidencing the effects of the economic uncertainty as result of the shocks of the pandemic, little or negligible research focusing on the impact of economic unpredictability of COVID-19 pandemic on volatility of stock and oil markets. This paper focuses to fill this research gap by using Vector Autoregressive (VAR) modelling.

\section{DATA AND METHODOLOGY}

\section{Data and Variable Setting}

The data used by the study comprised of the daily COVID-19 observations (measured by the new daily deaths and new daily cases in Kenya), the oil prices measured by the petroleum prices and stock prices measured by the Nairobi Securities Exchange (NSE). The data of COVID-19 related cases was collected from the ministry of health daily briefings.

The economic policy uncertainty was used as the key independent variable measuring the Kenyan economic uncertainty caused by COVID-19 pandemic. The economic uncertainty brought about by COVID-19 was measured by the extent to which pandemic-induced changes in business travel and working arrangements (Barrero, 2020). As such, the economic uncertainty in Kenya was measured by the number of business travel bans and restrictions during the pandemic.

The oil market volatility was captured by daily oil prices during the study period. A special focus was given to super diesel petroleum product which is highly used by large tracks transporting goods in Kenya. The data of daily prices of petrol was collected from the Energy and Petroleum Regulatory Authority (EPRA) website and official price posts by the authority.

The data selection period was restricted to $13^{\text {th }}$ March 2020- $30^{\text {th }}$ September2020. Thisyielded a sample size of 202 observations. The selection of data followed a purposive sampling technique which was deemed suitable for selecting the identified variables with special attributes in regards to impacts of COVID-19 pandemic. 
International Journal of Social Science and Economic Research

ISSN: 2455-8834

Volume:05, Issue:11 "November 2020"

\section{STATISTICAL MODELLING AND ANALYSIS}

\section{Normality Test}

In order to test for the normality of data, the study considered different normality tests. These included; Kurtosis, Jarcque-Bera and Skewness tests. A threshold of \pm 1 or \pm 2 for Kurtosis test statistic values, $<5.9$ for Jarcque-Bera test statistic value and \pm 3 for Skewness test values were considered. The stated threshold values were used as the rule of thumb of normally distributed data.

\section{Stationarity and Unit Root Test}

Any set of times series or historical data contains non stationarity and endogeneity traits that may result into spurious estimation results. Therefore, it is of great importance to check for the stationarity of the data. The study considered testing for the stationarity of unit root of the collected data of oil prices, stock prices, COVID-19 data of new cases and deaths, and economic uncertainty due to COVID-19 as proxied by the number of business travel bans and restrictions such as curfew days.

The study considered a combination of Augmented Dickey Fuller Test (ADF) by Dickey and Fuller (1979) and Phillips Perron test by Phillips and Perron (1988) to test for the stationarity of data of each variable. The use of the two tests was informed by the fact that ADF has low statistical power of distinguishing between true unit root and near unit root process. PP test on the other hand is more robust on different forms of heteroscedasticity. The ADF and PP tests will include both trend and intercept assumptions so as to ensure that deficiencies are eliminated. The rule of thumb was to reject null hypothesis if the PP and ADF test values are less than the critical value at $5 \%$ confidence interval. This was taken as an indication of the absence of unit root and if greater than then critical value at $5 \%$, accept the null hypothesis and conclusion be drawn that unit root exists.

\section{Lag Length Selection Test}

This test helped in determining the ideal number of lags on the basis of a preferable information criteria. This will study will give preference to the following two tests in line with (Naqqar and Al-Awad, 2012);

i. Akaike Information Criterion:

This can be expressed as; 
International Journal of Social Science and Economic Research

ISSN: 2455-8834

Volume:05, Issue:11 "November 2020"

$\operatorname{AIC}(\mathrm{P})=\log (\operatorname{Det} \mathrm{t}(\mathrm{t}))+2\left[\frac{n^{2} P}{N}\right]$. By further expressing this, the formula becomes; $\operatorname{AIC}\left(\mathrm{P}_{0}\right)$ $=\operatorname{Min}_{p=1}^{k} \operatorname{AIC}(P)$

A lag length whose value for AIC is smallest was put into consideration for further estimation.

\section{Granger Causality Test}

This test was used to evaluate the causal directional relationship between two variables, relying majorly on the F-Test. A variable say $\mathrm{X}$ is said to Granger cause another variable say $\mathrm{Y}$ if and only iff the time lags of variable $\mathrm{X}$ have a higher predictive power than that of the variable $\mathrm{Y}$ 's time lags. This followed a null hypothesis which states that $\mathrm{X}$ variable doesn't affect variable $\mathrm{Y}$, and thus rejection of the null hypothesis implies that $\mathrm{X}$ affects $\mathrm{Y}$ (time lag of variable $\mathrm{X}$ has extra predictive power on $\mathrm{Y}$ if added to the time lag of values of $\mathrm{Y}$ itself).

\section{Vector Autoregressive (VAR) Modelling}

The study followed unrestricted VAR technique in describing the impact of economic uncertainty of COVID-19 pandemic on volatility of oil and stock markets. VAR approach allows for endogeneity testing of several variables as well as the response of stock and oil prices to COVID-19 pandemic related shocks so as to capture the impact of economic uncertainty on stock and oil price variables. The reduced form of VAR specification for estimation is defined by the following dynamic equation;

$\mathrm{Yt}=\Upsilon_{0}+\sum_{k=0}^{n} \Upsilon_{i} Y_{t-1}+\varepsilon_{t}$

Based on the equation (1) above, $Y_{t}$ represents the variable vector. $\Upsilon_{0}$ represents the column vector of the constant term, represents the lag number. $Y_{t}=\left[Y_{1 t} \ldots \ldots \ldots . . Y_{k t}\right]$ is the representation of variable column vector in the estimation model (economic uncertainty, COVID-19 variables, oil price and stock price), whereas $Y_{i}$ represents the [k x k] matrix of indefinite estimations. The column vector of the random term is signified by $\varepsilon_{t}$. Following the works of Jurado (2015), the paper will consider a recursive identification approach whereby the measures of economic uncertainty of COVID-19 pandemic will be placed in the VAR model.

\section{Impulse Response Function}

This is one of the significant applications of VAR model used to identify the impact of any shock to the explanatory variables on the explained variable. Simply put, the function shows the number of time lags in which shocks to the explained variable will continue in the future until the impact of the said shocks disappear. 
International Journal of Social Science and Economic Research

ISSN: 2455-8834

Volume:05, Issue:11 "November 2020"

\section{DATA ANALYSIS AND DISCUSSION OF FINDINGS}

\section{Introduction}

This section entails analysis and presentation of the data findings. The section comprises of descriptive and summary statistics, normality test, stationarity test, VAR estimation and impulse function findings.

\section{Summary and Descriptive Statistics}

The collected data was analysed in terms of mean, minimum, maximum, and mean values. The findings were presented in table 1 .

Table 1: Descriptive Statistics

\begin{tabular}{llllll}
\hline & N_CASES & N_DEATHS & $\begin{array}{l}\text { ECON_UNCE } \\
\text { RTAINITY }\end{array}$ & OIL_PRICES & $\begin{array}{l}\text { STOCK_PRI } \\
\text { CES }\end{array}$ \\
\hline Mean & 188.0198 & 3.509901 & 101.5000 & 95.62297 & -0.265455 \\
Median & 123.0000 & 2.000000 & 101.5000 & 89.10000 & -0.089000 \\
Maximum & 1332.000 & 23.00000 & 202.0000 & 110.7000 & 4.5220000 \\
Minimum & 0.000000 & 0.000000 & 1.000000 & 83.35000 & -8.815000 \\
Std. Dev. & 221.1343 & 4.168396 & 58.45654 & 9.003920 & 1.4775840 \\
Observation & 202 & 202 & 202 & 202 & 202 \\
\hline
\end{tabular}

The findings presented in table 1 indicate the summary and descriptive statistics of the study variables. The average mean of new COVID-19 cases (N_CASES) is 188.0198 with the minimum being 0.000 and maximum being 1332.00. the average mean of new COVID-19 deaths (N_DEATHS) is 3.509901 with the lowest being at 0.000 and maximum being at 23.000 . The average economic uncertainty 101.5000, the minimum being at 1 and maximum being at 202 . The average oil prices (OIL_PRICES) is 95.62297 with the minimum at 83.3500 and the maximum being at 110.7000 . The average price (STOCK_PRICES) of stocks is -0.265455 , minimum being at -8.815000 and the maximum value being at 4.522000 .

\section{Normality Test}

The collected data was also subjected to normality test so as to assess whether it was normally distributed or not. The study considered three tests; Skewness, Kurtosis and Jarcque-Bera tests. The analysis findings were presented in table 2 . 
International Journal of Social Science and Economic Research

ISSN: 2455-8834

Volume:05, Issue:11 "November 2020"

Table 2: Normality Test Findings

\begin{tabular}{llllll}
\hline & N_CASES & $\begin{array}{l}\text { N_DEAT } \\
\text { HS }\end{array}$ & $\begin{array}{l}\text { ECON_UNCE } \\
\text { RTAINITY }\end{array}$ & OIL_PRICES & $\begin{array}{l}\text { STOCK_PR } \\
\text { ICES }\end{array}$ \\
\hline Skewness & 1.686180 & 1.852351 & $7.17 \mathrm{E}-17$ & 0.161783 & -2.223826 \\
Kurtosis & 2.304308 & 1.751909 & 1.799941 & 1.584682 & 2.455830 \\
Jarque-Bera & 1.618200 & 3.997100 & 2.121190 & 3.740810 & 1.005180 \\
Probability & 0.000000 & 0.000000 & 0.002333 & 0.000140 & 0.000000 \\
Observations & 202 & 202 & 202 & 202 & 202
\end{tabular}

The findings presented in table 2 show the normality test of the data distribution. Based on the findings, the Skewness statistic values of new COVID-19 cases (N_CASES), new COVID-19 deaths (N_DEATHS), economic uncertainty (ECON_UNCERTAINITY), oil prices (OIL_PRICES), stock prices (STOCK_PRICES) were; 1.686180, 1.852351, 7.17E-17, 0.161783 and -2.223826. Jarcque-Bera statistical values were; 1.618200, 3.997100, 2.121190, 3.740810, and 1.005180 respectively. The Kurtosis values were; 2.304308, 1.751909, 1.799941, 1.584682 and 2.45583. These values lie within the required thresholds of $\pm 3, \pm 1$ or \pm 2 , and $<5.9$ for Skewness, Jarcque-Bera and Kurtosis tests. The P-values $<0.05$, implies that a null hypothesis that the data is not normally distributed was rejected and a conclusion drawn that the data of the study variables was normally distributed.

\section{Stationarity Test}

The study considered by ADF and PP tests in analysing whether the data exhibit unit root traits or not at different level forms of differencing. The analysis findings of unit root test at level form were presented in table 3 .

\section{Table 3: Unit Root at Level Form}

\begin{tabular}{lllllll}
\hline Variable & Lag & ADF-C & ADF-T & PP-C & PP-T & Status \\
\hline N_CASES & 0 & -1.344 & -2.876 & -4.511 & -2.876 & Stationary \\
N-DEATHS & 0 & -3.762 & -2.876 & -8.666 & -2.876 & Stationary \\
ECON_UNCERTAINITY & 0 & -2.984 & -2.876 & 4.190 & -2.876 & Not Stationary \\
OIL_PRICES & 0 & -1.962 & -2.876 & -1.980 & -2.876 & Not Stationary \\
STOCK_PRICES & 0 & -6.821 & -2.876 & -6.727 & -2.876 & Stationary \\
\hline
\end{tabular}


International Journal of Social Science and Economic Research

ISSN: 2455-8834

Volume:05, Issue:11 "November 2020"

MacKinnon Critical Value at 5\%=-2.876

The findings presented in table 3 show the unit root traits of each variable at level form. The computed ADF (ADF-C) value for new COVID-19 cases, new COVID-19 deaths, economic uncertainty, oil prices and stock prices were; -1.344, -3.762, -2.984, -1.962 and -6.821 respectively. The computed PP(PP-C) test values are; $-4.511,-8.666,4.190,-1.980$ and -1.6727. comparing these values with the critical values (ADF-T and PP-T), the computed values are less than the critical values except for economic uncertainty and oil prices variables. This signifies that the data for new COVID-19 cases, new COVID-19 deaths and stock prices contained no unit root traits.

In order to make the data for economic uncertainty and oil prices, the data was differenced at first level of differencing. The differenced data was thereafter subjected into unit root test. The findings were presented in table 4.

Table 4: Unit Root Test at First Differencing

\begin{tabular}{lllllll}
\hline Variable & Lag & ADF-C & ADF-T & PP-C & PP-T & Status \\
\hline ECON_UNCERTAINITY & 1 & -4.257 & -2.876 & -5.124 & -2.876 & Stationary \\
OIL_PRICES & 1 & -14.076 & -2.876 & -14.076 & -2.876 & Stationary
\end{tabular}

The findings in table 4 show the unit root test findings at first differencing of economic uncertainty and oil prices variables. At first difference, the computed ADF (ADF-C) and computed PP (PP-C) values of economic uncertainty and oil prices were found to be; -4.257 and -14.076 , and -5.124 and -14.076 respectively. Comparing these values with the MacKinnon critical value at $5 \%$ confidence interval, the computed values are less than the critical values hence the null hypothesis that the data of economic uncertainty and oil prices is not stationary at first differencing was rejected and a conclusion drawn that the data is stationary at first differencing.

\section{Lag Order Selection}

Akaike Information Criterion (AIC) and Schwartz Bayesian Information Criterion (SBIC). A keen interest was given to AIC in establishing the lag order for model estimation of the variables exhibited different levels of lags. The findings were presented in table 5. 
International Journal of Social Science and Economic Research

ISSN: 2455-8834

Volume:05, Issue:11 "November 2020"

Table 5: Lag Order Selection

\begin{tabular}{llll}
\hline Variable & Lag & AIC & SBIC \\
\hline N_CASES & 1 & 12.61620 & 12.66551 \\
N_DEATHS & 1 & 5.235370 & 5.284673 \\
ECON_UNCERTAINITY & 1 & $1.454061^{*}$ & $1.470495^{*}$ \\
OIL_PRICES & 1 & 4.387361 & 4.436836 \\
STOCK_PRICES & 1 & 3.010993 & 3.060296
\end{tabular}

*denotes the smallest values

Based on the findings presented in table 5, the lag length that minimizes the AIC and SBIC value is lag of 1 . This implied that the model of estimation the relationship between the study variables was suitably estimated using a lag length of 1 .

\section{Granger Causality Test}

Granger causality test was carried out to determine the relationship between economic uncertainty of COVID-19 and oil prices, and stock prices. The findings were presented in table 6.

Table 6: Granger Causality Test Results

\begin{tabular}{llllc}
\hline Null Hypothesis: & Lag & Obs & F-Stats & Prob. \\
\hline N_CASES does not Granger Cause OIL_PRICES & 1 & 201 & 3.0352 & 0.083 \\
OIL_PRICES does not Granger Cause N_CASES & & & 1.4053 & 0.237 \\
N_DEATHS does not Granger Cause OIL_PRICES & 1 & 201 & 2.0559 & 0.153 \\
OIL_PRICES does not Granger Cause N_DEATHS & & & 4.4926 & 0.035 \\
ECON_UNCERTAINITY does not Granger Cause & 1 & 201 & 5.9168 & 0.016 \\
OIL_PRICES & & & & \\
OIL_PRICES does not Granger Cause & & & -190.11 & 1.000 \\
ECON_UNCERTAINITY & & 201 & 7.5091 & 0.007 \\
N_CASES does not Granger Cause STOCK_PRICES & 1 & 3.6886 & 0.056 \\
STOCK_PRICES does not Granger Cause N_CASES & & \multirow{2}{*}{201} & 0.8117 & 0.369 \\
N_DEATHS does not Granger Cause STOCK_PRICES & 1 & & 1.5404 & 0.216 \\
STOCK_PRICES does not Granger Cause N_DEATHS & & & & \\
\hline
\end{tabular}


International Journal of Social Science and Economic Research

ISSN: 2455-8834

Volume:05, Issue:11 "November 2020"

$\begin{array}{lllll}\text { ECON_UNCERTAINITY does not Granger Cause } & 1 & 201 & 0.0116 & 0.914\end{array}$

STOCK_PRICES

STOCK_PRICES does not Granger Cause $275.67 \quad$ 2.E-

ECON_UNCERTAINITY 39

The results in table 6 show that, there is no causal relationship between new COVID-19 cases and oil prices. This is depicted by the $\mathrm{P}$-value $=0.0830$ and $\mathrm{P}$-value $=0.2373$ which are greater than 0.05 at $5 \%$ confidence interval. Further, the findings revealed that there is a one-way causal relationship between new COVID-19 deaths and both oil prices and economic uncertainty with a $\mathrm{P}$-values $(0.0353)<0.05$ and $\mathrm{P}$-value $=(0.0159)<0.05$ respectively. This means that increased economic uncertainty as a result of increased number of deaths as a result of COVID-19 results into significant effect on oil prices.

Regarding the economic uncertainty of COVID-19 and stock market prices, the results showed that, there is a bidirectional causal relationship between new COVID-19 cases and stock prices with $\mathrm{P}$-values $=0.0067$ and $\mathrm{P}$-value $=0.0562$ being less than 0.05 at $5 \%$ confidence interval. A neway causal relationship exists between economic uncertainty and stock prices with a Pvalue $=2 . E-39<0.05$. A neutral causal relationship exists between new death COVID-19 cases and stock prices with $\mathrm{P}$-value $>0.05$ at $5 \%$ confidence interval.

\section{VAR and Impulse Response Function Findings}

The VAR estimation was presented in terms of impulse response functions and variance decomposition as indicated in figure 2 and table 7. Impulse response functions were used to study the response of the oil and stock market to economic uncertainty of COVID-19 pandemic. A generalized impulse response functions with dashed lines indicating the confidence bounds of $95 \%$. The application of the impulse response functions was informed by the studies of Giordano et al., (2007); and Diaz and de Gracia (2017). The impulse response functions were constructed with the assumption that the volatility or shocks resemble a 1\% of the new COVID-19 cases and deaths. Moreover, statistical significance is denoted by focusing on the estimates whose narrow error band doesn't include zero. The findings were presented as follows; 
International Journal of Social Science and Economic Research

ISSN: 2455-8834

Volume:05, Issue:11 "November 2020"

Response of ECON_UNCERTAINITY to N_CASES

Response of ECON_UNCERTAINITY to N_DEATHS
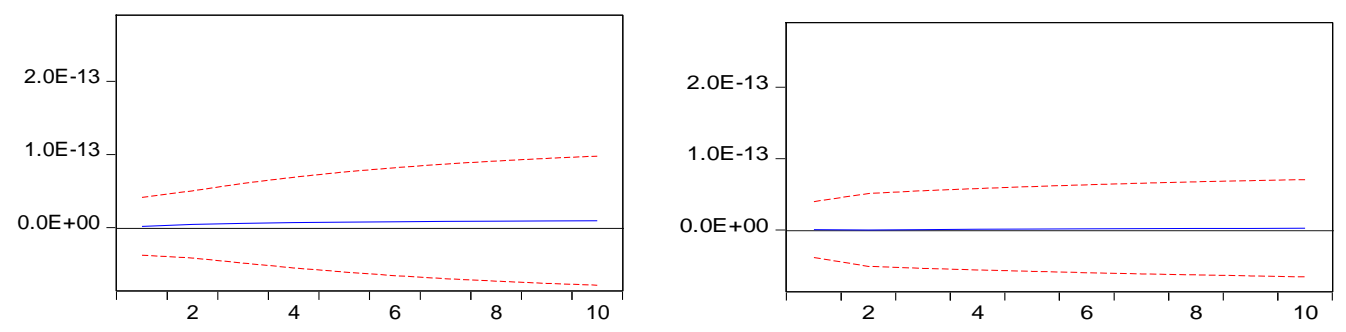

Response of OIL_PRICES to ECON_UNCERTAINITY

Response of OIL_PRICES to N_CASES
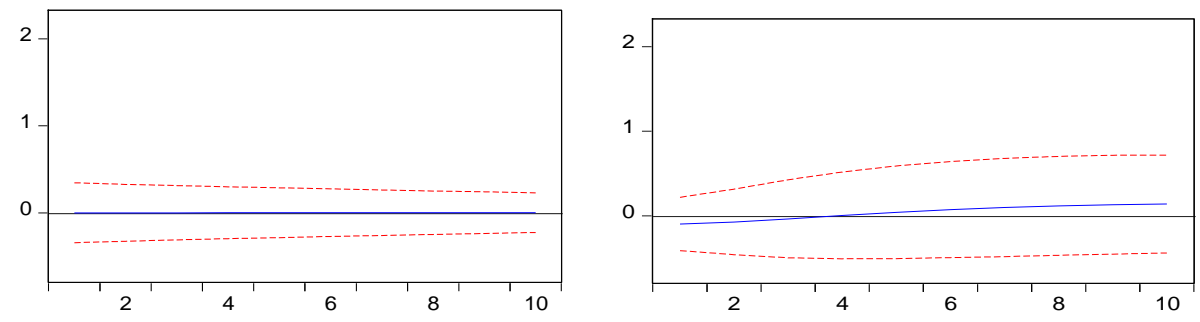

Response of OIL_PRICES to N_DEATHS

Response of STOCK_PRICES to ECON_UNCERTAINITY
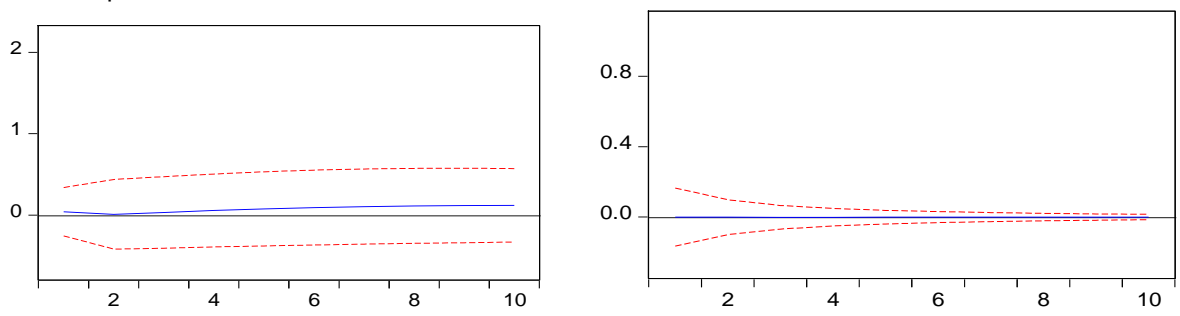

Response of STOCK_PRICES to N_CASES

Response of STOCK_PRICES to N_DEATHS
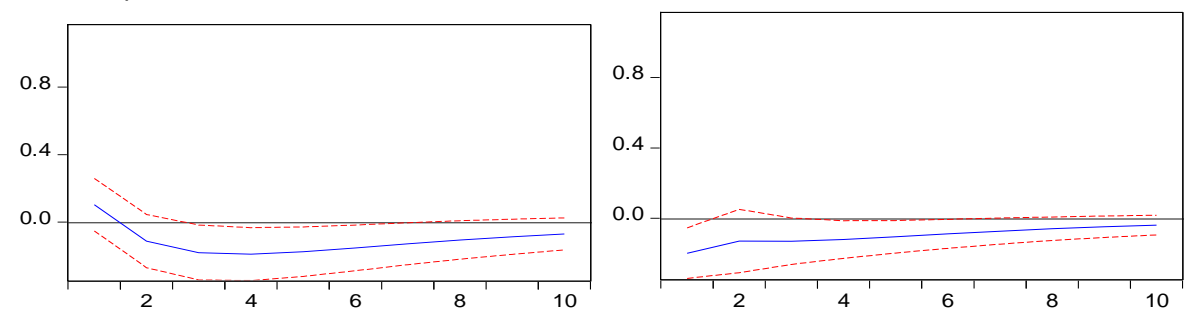

Figure 1: Plots of Impulse Response Functions to COVID-19 Pandemic

The impulse response functions presented in figure 1 show that impulse responses of oil prices, stock prices, economic uncertainty to a standardized deviation shock on new COVID-19 cases and deaths are statistically significant. 


\section{International Journal of Social Science and Economic Research}

ISSN: $2455-8834$

Volume:05, Issue:11 "November 2020"

With particular focus on energy market, the impulse response function shown indicates that a positive shock of economic uncertainty results to a decrease in the oil prices during the impact period. The shock persists until the $10^{\text {th }}$ period. In regards to response of oil prices on shocks of new cases and deaths caused by COVID-19 pandemic, the results showed that positive increase of new cases results to a decrease in oil prices up to $5^{\text {th }}$ period and later the prices pick up afterwards. Similarly, the oil prices increase simultaneously with increase in number of deaths though the impact is within zero. This affirms that the effect of new cases and deaths caused by COVID-19 is short lived. However, the positive response of oil prices to both new cases and deaths is slightly lower than the remaining periods. This is in agreement with the findings of other studies like (Albulescu, 2020]).

The results also showed that, the response of stock mark prices is significantly negative during the impact period especially in response to the new COVID-19 cases and certainly becomes increasing after $4^{\text {th }}$ period although on the negative side. The estimated effect is about $0.5 \%$. This applies also to response of stock market prices on new death cases caused by COVID-19. There is significant negative impact throughout the impact period but the impact dies at the $9^{\text {th }}$ period before it becomes negatively constant. In regards to the response of stock market prices on economic uncertainty, the results pointed out that there is significant negative impact.

As the economics uncertainty persists, the stock market prices become equally worst off with returns within zero from the negative side. The positive response of stock market volatility to COVID-19 pandemic cases is well presented in the literature. Increase in new cases and new deaths creates worst economic uncertainty associated with travel bans and business restrictions thereby increasing the stock market volatility as several stock investors lose confidence in the market. After the impact period, the stock market prices become better due to news of economic relief measures such as relaxation of travel restrictions which appear to have raised the prices of stock through reduction of investor's risk aversion as improved forecast on long run economic growth (Gorsen\& Koijen, 2020).

Table 7: Variance Decomposition

\section{ECON_UNCERTAINITY}

$\begin{array}{lcccc}\text { Period } & \text { N_CASES } & \text { N_DEATHS } & \text { OIL_PRICES } & \text { STOCK_PRICES } \\ 1 & 0.000000 & 0.000000 & 2.08 \mathrm{E}-06 & 5.46 \mathrm{E}-06 \\ 5 & 0.023517 & 0.000655 & 0.000837 & 0.000846 \\ 10 & 0.048769 & 0.000353 & 0.003375 & 0.000489\end{array}$


International Journal of Social Science and Economic Research

ISSN: 2455-8834

Volume:05, Issue:11 "November 2020"

\begin{tabular}{lllll}
\hline N_CASES & & & & \\
\hline Period & ECON_UNCERTAINITY & N_DEATHS & OIL_PRICES & STOCK_PRICES \\
1 & 0.004479 & 0.000000 & 0.211818 & 1.036031 \\
5 & 0.004311 & 2.178723 & 0.271551 & 3.067563 \\
10 & 0.004252 & 2.219609 & 0.301049 & 4.316393 \\
\hline
\end{tabular}

\begin{tabular}{lllll}
\hline N_DEATHS & & & \\
\hline Period & ECON_UNCERTAINITY & N_CASES & OIL_PRICES & STOCK_PRICES \\
1 & 0.000332 & 5.965791 & 0.039220 & 3.569178 \\
5 & 0.001058 & 22.03322 & 0.077110 & 6.386715 \\
10 & 0.001150 & 24.07991 & 0.081483 & 7.055898
\end{tabular}

\section{OIL_PRICES}

$\begin{array}{lllll}\text { Period } & \text { ECON_UNCERTAINITY } & \text { N_CASES } & \text { N_DEATHS } & \text { STOCK_PRICES } \\ 1 & 0.000000 & 0.000000 & 0.000000 & 0.000000 \\ 5 & 1.07 \mathrm{E}-05 & 0.244382 & 0.106549 & 1.665676 \\ 10 & 4.25 \mathrm{E}-05 & 0.950072 & 0.093016 & 3.160912\end{array}$

\begin{tabular}{llcll}
\hline STOCK_PRICES & & & \\
\hline Period & ECON_UNCERTAINITY & N_CASES & N_DEATHS & OIL_PRICES \\
1 & 0.000000 & 0.000000 & 0.000000 & 0.672252 \\
5 & 0.000379 & 8.343574 & 0.112109 & 0.982143 \\
10 & 0.000520 & 11.41696 & 0.206736 & 1.101133 \\
\hline
\end{tabular}

The findings presented in table 7 show the variance decomposition presents the forecast error estimates up to $10^{\text {th }}$. In regards to energy market volatility, it is notable that the economic uncertainty, new COVID-19 cases and new COVID-19 deaths explains about $0.000 \%$ in the first period respectively. In the $5^{\text {th }}$ period, the power of the pandemic increases to $1.07 \mathrm{E}-05 \%$, $0.244 \%$, and $0.107 \%$ for economic uncertainty, new cases and new deaths of COVID-19. The variance error share due to COVID-19 pandemic increases further to $4.25 \mathrm{E}-05 \%, 0.95 \%$, and $0.09 \%$ for economic uncertainty, new cases and new deaths of COVID-19 in the $10^{\text {th }}$ day. 
International Journal of Social Science and Economic Research

ISSN: 2455-8834

Volume:05, Issue:11 "November 2020"

In regards to stock market volatility, the results showed that; the economic uncertainty, new cases and new deaths caused by COVID-19 pandemic were; $0.00 \%$ in the $1^{\text {st }}$ day. The variance power increased further to $0.000379 \%, 8.344 \%$ and $0.112 \%$ in the $5^{\text {th }}$ day. In the $10^{\text {th }}$ day the pandemic power increased further to $0.000520 \%, 11.42 \%$ and $0.207 \%$. This implies that the error variance in stock market prices due to economic uncertainty caused by new cases and deaths of COVID-19 pandemic is greater than that of the oil market in regards to Kenyan economy.

\section{Conclusion}

The study explored the effect of economic uncertainty caused by COVID-19 pandemic on oil prices, and stock market vitality in Kenya for period between $13^{\text {th }}$ Match 2020 to $30^{\text {th }}$ September, 2020 using vector autoregressive (VAR) model. The findings pointed out that although the positive cases of COVID-19 pandemic infections had negative effects on oil prices, the effect is short lived. Nonetheless, the economic uncertainty shocks caused by COVID-19 pandemic such as travel bans and business travel restrictions had negative effect on both oil and stock market volatility throughout the forecasting period. By comparing the impacts, the economic uncertainty caused by new cases and new deaths of COVID-19 pandemic have stronger impact on the stock market volatility as compared to the oil market prices. Therefore, in light of this, concerted efforts should be enacted by the Kenyan government so as to speed the economic recovery. These may include easing on business travel restrictions and reduced interest rates. This will increase money supply and by extend increased lending to the business investments.

\section{References}

1. Albulescu, C. (2020). Coronavirus and oil price crash. Available at SSRN 3553452.

2. Al-Awadhi, A. M., Al-Saifi, K., Al-Awadhi, A., \&Alhamadi, S. (2020). Death and contagious infectious diseases: Impact of the COVID-19 virus on stock market returns. Journal of Behavioral and Experimental Finance, 100326.

3. Aloui, R., Gupta, R., \& Miller, S. M. (2016). Uncertainty and crude oil returns. Energy Economics, 55, 92-100.

4. Antonakakis, N., Chatziantoniou, I., \&Filis, G. (2014). Dynamic spillovers of oil price shocks and economic policy uncertainty. Energy Economics, 44, 433-447.

5. Badshah, I., Demirer, R., \&Suleman, M. T. (2019). The effect of economic policy uncertainty on stock-commodity correlations and its implications on optimal hedging. Energy Economics, 84, 104553. 


\section{International Journal of Social Science and Economic Research}

ISSN: $2455-8834$

Volume:05, Issue:11 "November 2020"

6. Baker, S. R., Bloom, N., Davis, S. J., \& Terry, S. J. (2020). Covid-induced economic uncertainty (No. w26983). National Bureau of Economic Research.

7. Balcilar, M., Wen, E., Gupta, R., \&Roubaud, D. (2017). Can volume predict Bitcoin returns and volatility? A quantiles-based approach. Economic Modelling, 64, 74-81.

8. Basher, S. A., \& Sadorsky, P. (2016). Hedging emerging market stock prices with oil, gold, VIX, and bonds: A comparison between DCC, ADCC and GO-GARCH. Energy Economics, 54, 235-247.

9. Baumeister, C., \& Hamilton, J. D. (2019). Structural interpretation of vector autoregressions with incomplete identification: Revisiting the role of oil supply and demand shocks. American Economic Review, 109(5), 1873-1910.

10. Baumeister, C., \& Peersman, G. (2013). Time-varying effects of oil supply shocks on the US economy. American Economic Journal: Macroeconomics, 5(4), 1-28.

11. Bernanke, B. S., Kiley, M. T., \& Roberts, J. M. (2019, May). Monetary policy strategies for a low-rate environment. In AEA Papers and Proceedings (Vol. 109, pp. 421-26).

12. Barrero, J. M., Bloom, N., \& Davis, S. J. (2020). Covid-19 is also a reallocation shock (No. w27137). National Bureau of Economic Research.

13.Chen, F., Wu, S. T., \& Liao, S. Y. (2020). Decomposing a time-frequency relationship between economic policy uncertainty and tourism in the G8 countries through wavelet analysis. Journal of Policy Research in Tourism, Leisure and Events, 1-19.

14. Chuah, L. L., Loayza, N., \& Myers, C. B. (2020). The Fight against Corruption: Taming Tigers and Swatting Flies. World Bank Research and Policy Briefs, (145050).

15. Degiannakis, S., Filis, G., \&Panagiotakopoulou, S. (2018). Oil Price Shocks and Uncertainty: How stable is their relationship over time? Economic Modelling, 72, 42-53.

16. Demirer, R., Gupta, R., \&Pierdzioch, C. (2020). Infectious Diseases, Market Uncertainty and Oil Market Volatility. Energies, 13(16), 4090.

17. Diebold, F. X., \& Yilmaz, K. (2012). Better to give than to receive: Predictive directional measurement of volatility spillovers. International Journal of Forecasting, 28(1), 5766.

18. Dietrich, A., Keuster, K., Müller, G. J., \&Schoenle, R. (2020). News and uncertainty about covid-19: Survey evidence and short-run economic impact. 
International Journal of Social Science and Economic Research

ISSN: 2455-8834

Volume:05, Issue:11 "November 2020"

19. Dickey, D. A., \& Fuller, W. A. (1979). Distribution of the estimators for autoregressive time series with a unit root. Journal of the American statistical association, 74(366a), 427431.

20. Gkillas, K., Gupta, R., \&Pierdzioch, C. (2020). Forecasting realized oil-price volatility: The role of financial stress and asymmetric loss. Journal of International Money and Finance, 102137.

21. Hailemariam, A., Smyth, R., \& Zhang, X. (2019). Oil prices and economic policy uncertainty: Evidence from a nonparametric panel data model. Energy Economics, 83, 40-51.

22. Hamilton, C. (2020). My heart feels chained": The effects of economic precarity on Syrian refugee parents living in Lebanon. Political violence toward children: Psychological effects, intervention and prevention policy, 1264-1273.

23. Johansen, S. \&Juselius, K. (1990), "Maximum Likelihood Estimation and Inference on Cointegration with Applications to the Demand for Money," Oxford Bulletin of Economics and Statistics, 52(2), 169-210.

24. Jurado, K., Ludvigson, S. C., \& Ng, S. (2015). Measuring uncertainty. American Economic Review, 105(3), 1177-1216.

25. Kanaan, A. \& Al-Jabbouri, A. (2012), "Comparative Study on Estimating the Regression of Cointegration with a Practical Application," Iraqi Journal of Economic Sciences, 10(33), 151-172.

26. Kang, W., Ratti, R. A., \&Vespignani, J. L. (2017). Oil price shocks and policy uncertainty: New evidence on the effects of US and non-US oil production. Energy Economics, 66, 536-546.

27. Liu, I. C., \&Illing, T. Y. (2019). Local institution contingencies for the effects of local market orientation on foreign SMEs' performances: evidence from an emerging market. Jiao Da Guan Li XueBao, 39(1), 1-47.

28. Loayza NV, Pennings S (2020) Macroeconomic policy in the time of covid-19: A primer for developing countries. Research \& Policy Brief No.28. Ma, F., Zhang, X., \& Zhang, Y. (2020). Economic policy uncertainty and the Chinese stock market volatility: Novel evidence. Economic Modelling, 87, 24-33. 
International Journal of Social Science and Economic Research

ISSN: 2455-8834

Volume:05, Issue:11 "November 2020"

29. McKibbin WJ, Fernando R (2020) The global macroeconomic impacts of COVID-19: Seven scenarios. CAMA Working Paper.

30. Naqar, O. \& Awad, M. (2012), "Using VAR Models in Predicting and Studying the Causal Relationship between Gross Domestic Product and Total Capital in Syria," Damascus University Journal of Economic and Legal Sciences, 28(2), 337- 360.

31. National Treasury. (2020). Medium Term Budget Policy Statement. February 2020. Nairobi.

32. Phillips, P. C., \& Perron, P. (1988). Testing for a unit root in time series regression. Biometrika, 75(2), 335-346.

33. Sadorsky, P., 2006. Modeling and forecasting petroleum futures volatility. Energy Economics 28, 467-488.

34. Salami, A. \&Sheikhi, M. (2013), "The Test of the Causal Relationship and the Cointegration between Savings and Investment in the Algerian Economy during the Period (19702011)," Al-Bahith Journal, 13, 121-134.

35. Shahzad, S. J. H., Raza, N., Balcilar, M., Ali, S., \&Shahbaz, M. (2017). Can economic policy uncertainty and investors sentiment predict commodities returns and volatility? Resources Policy, 53, 208-218.

36. Wen, F., Xiao, J., Xia, X., Chen, B., Xiao, Z., \& Li, J. (2019). Oil prices and Chinese stock market: Nonlinear causality and volatility persistence. Emerging Markets Finance and Trade, 55(6), 1247-1263.

37.WHO (2020) Coronavirus disease (COVID-19) outbreak. Available from: https://www.who.int/westernpacific/emergencies/covid-19.

38. Worldometer (2020) Coronavirus Pandemic. Available from: https://www.worldometers.info/coronavirus/.

39. Yang, L. (2019). Connectedness of economic policy uncertainty and oil price shocks in a time domain perspective. Energy Economics, 80, 219-233.

40. Zaremba, A., Kizys, R., Aharon, D. Y., \&Demir, E. (2020). Infected Markets: Novel Coronavirus, Government Interventions, and Stock Return Volatility around the Globe. Finance Research Letters, 101597.

41. Zhang, X., \& Zhang, Y. (2020). Economic policy uncertainty and the Chinese stock market volatility: Novel evidence. Economic Modelling, 87, 24-33. 
International Journal of Social Science and Economic Research

ISSN: 2455-8834

Volume:05, Issue:11 "November 2020"

42. Zhao, Y., Li, J., \& Yu, L. (2017). A deep learning ensemble approach for crude oil price forecasting. Energy Economics, 66, 9-16. 